\title{
Football Fans in the "Südkurve": An Escape from the Pressure to Singularize?
}

\author{
Jo Reichertz ${ }^{1}$ (D)
}

Received: 28 June 2021 / Revised: 11 January 2022 / Accepted: 12 January 2022

(C) The Author(s) 2022

\begin{abstract}
With remarkable regularity, escalation processes in soccer stadiums lead to violence between police, private security guards, and soccer fans. This article examines the question of how this happens and what it means. In a consideration of Reckwitz's thesis of the society of singularities, data from participant observation, interviews, and video analysis is examined in order to address the question of whether going to soccer games can be understood as a temporary break from the compulsion to individualize or singularize. In addition, the article develops the thesis that the escalation of processes of violence does not constitute the collapse of social order, but rather a predictable process in which all participants consistently cooperate (Collins). Through ordered togetherness and opposition, a common ritual (Durkheim and Turner) takes place, an always precarious walk up to the limits of what is socially acceptable, which also leads to the renewal of the social. Going to soccer stadiums, so my thesis, can be understood as testing the boundaries of the socially acceptable.
\end{abstract}

Keywords Escalation of violence $\cdot$ Pressure to singularize $\cdot$ Society of singularities · Qualitative research

\section{Late Modernity and the Pressure to Individualize}

As wide-view contemporary diagnostics agree ${ }^{1}$, modernity's impetus to rationalize brought with it the promise and hope that human relationships, deep-seated emotions, and the insurmountable contingency of life can be discursively and cognitively processed, shaped, and safeguarded with

\footnotetext{
${ }^{1}$ In every football (American: soccer) stadium there is a certain spectator area, usually behind a goal, where mainly the very active home fans gather, that is, the ultras and in the past also the hooligans. There, the fans perform choreographies with large flags, beat drums, and sing loudly to cheer on their team. Fireworks or flares are often set off there as well. At the stadium of Borussia Dortmund, BVB, a leading Bundesliga club in Germany, this is the so-called Südkurve, which is celebrated by the home team and generally feared by the visiting team.
}

Jo Reichertz

Jo.Reichertz@kwi-nrw.de

1 Kulturwissenschaftliches Institut Essen Essen, Nordrhein Westphalen, Germany 
the help of reason and contracts (e.g., Beck, 2015; Giddens, 2001; Poferl \& Sznaider, 2020). This development is (also) the result of a secularization of social culture that has been going on for several centuries and is still continuing today, especially in the global North (Genov, 2018). The general process of secularization and rationalization that has been taking place since the Enlightenment has eroded the foundations of religions and societies (Beck, 2015; Giddens, 1997, 2013), and with them the cultural commitments for a successful life: step by step, this process has handed the problem of the right way of living over to the acting subject, who increasingly has to design "the world from his or her own ego" (Wanke, 2001: 18).

This tendency is reinforced by the broad process of globalization supported and driven by media, as well as the mediatization process (Couldry \& Hepp, 2016; Hepp, 2019; Reichertz, 2017): multicultural societies are impacted by contact compulsion (Soeffner, 2007); their cultural foundations, whose unity has always been problematic, is no longer as coherent as it was in pre-modern times (cf. Pfadenhauer \& Hitzler, 2020; Poferl, 2019; Strohschneider, 2020). Diversification and fragmentation of interpretations of the world and offers of meaning are globally observable consequences of encounters between cultures (Reichertz, 2021). Social differentiation further strengthens subjects' pressure to individualize.

Freed from religion and societal coercion, individualized subjects have to pause in this situation, as they face new pressures to determine themselves through their own power and their own decisions (with the help of the global offerings of the media). It is necessary for them to determine who they are and where they are in society, which norms are valid for them, which life projects they should pursue, and which goals and norms they should use to orient their own lives (and life with others) (Beck \& Beck-Gernsheim, 1994). In short, against the background of a lack of overarching meaning (anchored in the beyond), subjects are challenged to decide for themselves about the meaning of their own lives and the forms and norms of life that follow from it (Luckmann, 2010). They are compelled to bind themselves (with the help of reflection and the media) to certain plans of action and to renounce others, first to exclude themselves (in two ways) from the group and thus to designate themselves as unique, and then to establish themselves (Reichertz, 2000, 2015). In other words, they must find out or choose who they are or rather want to be, in order to subsequently anchor this identity and make it visible through social action. Subjects must first locate themselves with the help of self-created self-determination (which results from self-exclusion), in order to then find their way through the chaos of options to be able to determine themselves (Degen et al., 2020; Gross, 1994; Reichertz, 2010).

This has consequences for the individualized actors of late modern societies. They are, in a sense, "released from social-structural determinants [...] into the ambivalent 'freedom' of the private sphere and 'untenable' individual autonomy" (Knoblauch, 1991, 1). Following the internalized credo of late modernity, the actors who see themselves as individualized believe that their decisions produce the kind of differences that make a real difference, that is, that it essentially depends on them which path their lives will take. ${ }^{2}$ Therefore, it

\footnotetext{
${ }^{2}$ In my view, the repeatedly diagnosed pressure to individualize and subjectivize has led only to a very limited extent to individualization in the sense that each individual has actually become unique in terms of what he or she thinks, how he or she decides, what he or she believes in, and according to which norms he or she acts. Under the banner of wanting to be a unique individual or, more precisely, to have unique individuality, masks of the authentic (Fromm \& Reichertz, 2002) distributed by mass media and uniform cultures of selfpresentation have developed, resulting in many individuals doing very similar things in great unanimity, and presenting themselves as unique in the same way. A telling example of this is self-representation practice on the dating platform Tinder. Here, all users are called upon and strive to present themselves uniquely in their uniqueness - after all, they have to distinguish themselves from others and thus stand out from the crowd.
} 
is necessary to make decisions about everything, even about the meaningfulness of (one's own) life. The right meaning of life is no longer a default that is worked out socially and guaranteed, but above all an individual task, which carries the risk of failure. For the time being, there is no alternative to this "risk society" (Beck, 2015) with its "structural individuation and partialization not only of 'life situations' and 'lifestyles,' but also of religion" (Soeffner, 1994: 296); it is imposed on everyone and cannot be deselected (Poferl, 1999, 2019).

The pressure to isolate oneself is sweetened with the promise of becoming autonomous, of being able to decide for oneself how one wants to live, which God one believes in, and which norms and values one follows. In brief, with secularization comes the promise of making oneself unique, of standing out recognizably from others and being unmistakable, but also no longer being one with a group (and thus being like others), but only with oneself. Ultimately, it is the promise of making oneself the most important and final goal of one's actions, that is, ultimately making oneself God.

However, there are some people who are well equipped for this task and others who are not. Such a task may be somewhat pleasing to experienced lifestyle surfers who are well endowed with economic resources, including the highly educated creative world creators who can design and test new versions of themselves and the world again and again with a certain ease. In contrast, it is a dangerous burden to all those whose cultural as well as economic capital has turned out to be low.

At the same time, the permanent pressure to self-exclusion-or in Andreas Reckwitz's terms, the pressure to singularize (Reckwitz, 2019) - may structurally overwhelm the individual, and it may therefore also be necessary (or at least very pleasant) to occasionally give this pressure a rest, to take a short break, and in this break to experience that which (if one follows Durkheim, 1984 and Turner, 1995) renews one's strength to withstand the everyday compulsion to secularize. I would like to pursue these theses (by Reckwitz, Durkheim and Turner) in the following pages by turning to a case study of the group of passionate football fans who regularly go to football matches, where they repeatedly commit or suffer violence together and systematically communitize themselves in the process. In this way, I will try to show that the experience of violence and communitization can also be understood as a pleasurably experienced suspension from the singularity pressure.

My argumentation is drawn from a DFG project entitled Emotion: Escalation. Violence. ${ }^{3}$ Although we did not achieve one important goal, namely the development of a video-based procedure for the early detection of emotional processes at large-scale events, ${ }^{4}$ a wealth of sociologically valuable results emerged nevertheless, for example, clues regarding the conditions under which individuals willingly join together to form a community that is prepared to exercise and suffer violence.

My goal in this article is to examine and differentiate two theoretical concepts: On the one hand, I will empirically test the thesis of Reckwitz (2019), according to which there is

\footnotetext{
Footnote 2 (continued)

One might assume that creativity and uniqueness are the order of the day here. However, if one examines these representations - that is, the self-semiotizations of users - it becomes apparent that they all try to conform to certain typical ideas of socially recognized attractiveness, with the result that they are very similar to one another (cf. Degen \& Kleeberg-Niepage, 2021, see also Keysers 2018).

3 The project ran from 02/01/2015 until 01/31/2018. A comprehensive project report can be found in Reichertz \& Keysers, 2018.

${ }^{4}$ For a discussion of whether escalations in violence can be automatically detected by a camera, see Reichertz, 2019.
} 
a massive pressure on individuals in Germany (and in all postmodern societies) to repeatedly distinguish themselves from others by making decisions. Thus, the article presents a contemporary diagnosis. On the other hand, with the help of the analysis of empirical data, I will show that violence arises in particular situations, but cannot be explained by the situation alone. ${ }^{5}$ In doing so, I do not fundamentally contradict Randall Collins's theory of violence (Collins, 2011, 2016), instead demonstrating that other factors must be taken into account in order to explain the emergence of violence. In addition, I develop the thesis that the escalation of processes of violence does not constitute the collapse of social order, but rather (as Durkheim and Tuner have laid out) a common ritual, an always precarious walk up to the limits of what is socially acceptable.

\section{Going to the Football Stadium as a Leisure Activity}

Going to the football stadium is part of everyday urban life almost everywhere in the world. In German cities, too, millions of people (mostly men) from all educational backgrounds gather in football stadiums on Fridays, Saturdays, and Sundays (and recently also Mondays), as well as Tuesdays and Wednesdays during the league's English weeks, to watch "their" team play, cheering them on or booing them. Media coverage of football matches extends before and after the games, and the games themselves are broadcast either live or canned on public or private radio and television programs, either in their entirety or in excerpts, increasingly for a price (Sky, DAZN, etc.).

Among the on-site spectators, whether it is sunny or rainy, there are those who organize in clubs and associations to support "their" club by many means: these are the active fans or, more recently, the ultras. Some of the organized spectators (the "hools," for exampleClaus, 2017) attend the game (perhaps) only because of the expected confrontations. Most spectators, however, are not organized: they come in pairs or small groups, meet before the game, and stay together for a short time afterward. For them, football is the "most beautiful pastime in the world" to be enjoyed on the weekend; for some, on the other hand, football is life, or rather, football becomes something like the equivalent of religion (Bauer, 2006). For the latter group in particular, going to the football stadium consists of a multitude of other actions, of which watching and experiencing the game is only a small and not always the essential part. For these fans, being an active football fan-and this is especially true for ultras-means belonging to a social world of their own surrounding football (for general information on being a fan, see Roose et al., 2017).

Going to the football stadium begins long before the game for those involved in this world. During the journey to and from a football match, these fans literally get closer to each other, as they usually travel individually or together in buses and trains or walk the same routes. They recognize each other by their clothing or just by their common destination. At so-called high-risk games, the visiting fans/ultras are often met at the train station by the police and taken to the stadium by buses or escorted to the stadium under protection.

\footnotetext{
5 This analysis is based on a series of case studies (videos, field observations, interviews, and documents), including the following: interviews with police officers from 100-officer units with different functions, officers with inside knowledge of the fan scene, members of fan projects, and ultras $(\mathrm{N}=42)$, all of which were analyzed hermeneutically and/or according to the content; several field observations and field experiences $(\mathrm{N}=24)$ in the context of the project (football games, demonstrations, rock concerts); analysis of videos produced in the project (experiments with emotionalized groups and videos of groups in football stadiums, demonstrations, and rock concerts; and surveys and analysis of relevant YouTube videos $(\mathrm{N}=45)$.
} 
Time and again, however, active fans/ultras in particular try to evade this police escort/surveillance/restraint by arriving by car, boat, bus, and then walking to the stadium using new routes, or arriving via "alternative train routes" without police escort. This often results in entire groups of fans being detained and/or sent away by police forces.

The above-described processes of weekly collective communitization in and around football stadiums and the associated processes of densification and demarcation usually lead to the emergence of two or more groups of very active fans, each of which sees itself as a separate entity. The groups first recognize each other as opponents/enemies (home fans, visiting fans), and then begin to interact loudly with each other (singing, chanting slogans and insults). Another group of actors is usually part of the fixed ensemble of the overall event as well, namely public as well as private security guards and law enforcement offices, above all, police. According to their explicit self-image, this group wants to ensure that the opposing parties cannot clash directly in order to prevent the outbreak of acts of violence. However, from the fans' point of view, they appear mostly as adversaries, sometimes imposing very clear and illegitimate tangible limits on the legitimate wishes of the fans. This is probably why, in this worldview, fans and police are seen as "natural opponents" (cf. Feltes, 2013).

\section{How Do Escalation Processes Proceed?}

First and foremost, the term "escalation" means only the dynamic process of intensification of the emotional state of excitement, that is, the process of increasing. However, from the point of view of those involved, the situation has only escalated when mild or serious acts of violence have occurred. Escalation in this context thus refers to the process as well as the outcome. I use the term escalation as a label for processes that escalate toward violence, whose vanishing point is the outbreak of physical violence.

Yet the escalation process does not develop inevitably in a straight line toward the end point, the brief exchange of violent acts. Analytically, the escalation process in its initial consolidation can be divided into the following phases; empirically, however, the transitions between the stages are often fluid and this process does not always pass through all phases.

The first phase is characterized by the spatially close gathering (standing, walking) of very many individuals or even small groups with different, scattered targets of attention. This is often the case during arrival and departure. It is noticeable that the behavior of participants (above all the active fans, but also the spectators more generally) is primarily directed outward: in the course of the gathering, people meet each other less and less with civil inattention (Goffman, 1963: 101), but appropriate clothing and volume when speaking, voice pitch and occasional chants, gestures and body movements all show that people know where they are, that they are not alone, and that they know how they have to behave. Attention and many actions are directed outward, appealing to the senses of others, creating gateways of accessibility for others, thus laying the groundwork for shared action: Everyone exhibits increased body tension, gestures are "louder," and there is an increased willingness to interact and communicate. Moreover, all sensory channels are wide openone looks and listens to determine who others are and what they are up to, thus showing that one belongs, that one is (strongly) engaged in what is happening and expects others to be engaged as well. While communication does involve the linguistic signs that one sends 
out (louder than usual) (Reichertz, 2009, 2020), it is primarily the body that "radiates" to others (Goffman, 1971, p. 35).

Often, and this is the next phase, this scattered focus of attention with increased willingness to make contact is directed toward specific events or people, either by the crowd of people or through external impulses (walkways, barriers, etc.), which leads to a large number of people focusing together on one event (game) or one goal (as in a run on the ticket counter). Correspondingly, participants move even closer together, touching each other more and falling into the same forms of touching. Scattered attention and loose contact turn into shared attention and closer physical contact.

If shared attention and physical contact become very intense (longer, more frequent, denser, more emotional), those present usually begin to increasingly synchronize their bodies, their attention, and their actions, "recognizing" and understanding themselves as a unit. Synchronization means that the participants align their behavior in two ways, namely (a) certain modes of behavior are performed at the same time and in the same rhythm (parallelization), and/or (b) certain modes of behavior are expressed in the same temporal succession (sequentialization).

Group formation and the processes of focusing and synchronization (brought about by and supporting the group) are accompanied by a continuous increase in and mutual alignment of the emotional arousal level. Participants are together in an emotionally charged atmosphere of well-being or aggressiveness. The joint experience of these emotions and their reflection by others intensifies the emotional experience.

Additionally, group formation and the supporting processes of focusing and synchronizing are accompanied by the formation of (temporary) territories (Goffman, 1971). A group usually claims a certain space for itself and appropriates it by staying there, occupying it. Sometimes, when local fans and visiting fans clash in such a space, the territorial issue is dominant. However, it is always necessary to negotiate where the territory begins and where it ends. Within the territory, specific rules apply and the territory divides the overall present space-into our space and the space of the others. Certain spaces are particularly symbolically loaded, such as the "home curve" or one's own playing field.

In some situations, the recognition of the unity of one's own group is accompanied by the recognition of another, usually opposing group. This group is recognized as hostile and often visibly and vociferously confronted with its otherness - and usually its lesser importance-which leads to the development of an inside-outside dichotomy (us-them). Socially understood as a friend-foe scheme, this dichotomy is accordingly emotionally charged. By this phase at the latest, physiological changes of the organism occur in all participants: The release of adrenaline and cortisol leads to an increase in heartbeat, muscle tension, etc. These changes also affect the outside of the body and are thus visible and recognizable for friend and foe alike - albeit mostly at very close range.

At the same time, the actions of the opposing side are typified against the background of one's own knowledge and relevant experience, clarified, and "recognized" as parts of typical situations (frames) (as in a run on the ticket counter). This leads to the activation of one's own typified and rehearsed plans of action (scripts), and to the design, legitimization, and execution of individual courses of action (for example, chanting, throwing objects, igniting pyrotechnics, clearing of spaces by the police). Simultaneously, all groups involved experience the systematic and profound depersonalization and desubjectivization of the respective opposing side, albeit usually only briefly: one no longer sees the individual in the other, but only the enemy, the mob, the pack, the faceless masses. Individuals have lost their faces for each other in the strict sense. They no longer act only individually, 
but above all against the background of the social expectations of the group that surrounds them, of which the individual is a part.

Once these frames and scripts are established, along with mutual depersonalization and desubjectivization and the emotionalized bodily state, individuals voice ritual insults and provocations. Provocations are always more or less serious breaches of norms: the provocateur does something in public that one is normally not allowed to do, thus compelling the person addressed to react to the breach of norms, especially if that person is trying to keep order (police, security guards, teachers, etc.). If the provoked person does not react, he quickly loses face/credibility, or he wins and becomes a hero. This is why provocations are a good arena for heroes - on both sides. In the stadium, provocations often take the form of loud insults and/or gestures, for example, the off-with-the-head gesture in the form of an implied slitting of the throat, the raised middle finger, or the come-hither gesture.

Provoking or provocation plays a special role in football culture. This is because provocation is the central means used by many actors in the weekly football festival to set a particular dynamic in motion. "Provocations are strategic elements of collective action and basic patterns of a symbolic practice in which the actors make sure of their images of themselves and others, support their constructions of reality, and keep the movement moving. Provocations are as much methods of self-representation as they are of conflict escalation. Those who provoke show what they are like and what they take the other for" (Paris, 2015, p. 49). Provocations are particularly well suited to assigning certain identities to oneself and others: it turns out that under their masks, the seemingly good others are really the bad ones, and that oneself is only the victim of gratuitous aggression. As Reiner Paris so aptly describes, provocations are "triggers and amplifiers of circular social conflicts. (...) Provocations challenge reaction, which in turn can be perceived as provocation. (...) There is a mechanism of provocation, which, once set in motion, 'automatically' brings the actors into typical zugzwänge that they then can no longer avoid. (...) It contains an implicit program of action that often asserts itself even against the further intentions of the participants" (Paris, 2015, p. 49).

Those involved in provocation also include those who are in the vicinity. This is because provocations are always theatrical: they are not only directed at the addressed opponent, but always at the bystanders as well, who quickly become the audience-which is why provocations are always very loud. Whether they like it or not, bystanders quickly become involved in the overall event and have to take sides. Usually they take the side of the apparent victim who was the starting point of the provocation; the provocation exposes the evil character of the provoked policeman, which then almost automatically triggers the solidarity effect among bystanders (Spiekermann, 2018).

The special feature of provocation is its reciprocity: if the provocation is to succeed, the provoked person must react in the desired way, that is, by being offended and becoming angry or aggressive. Provocateurs who are left to their own devices are ridiculous figures. Therefore, they tend to invade the territories of the self (Goffman, 1971) with increasingly clear interventions until the other reacts in the desired way. In this respect, provocation is always inscribed with intensification-if necessary up to the point of violence. Therefore, no provocation is harmless, especially not when it disguises itself as a reaction to provocation already suffered.

But provocation requires surprise. Those who know that they are being provoked can avoid it. If provocation becomes an anticipatable action, if it becomes ritualized and thus expectable as a certainty, it loses its sting, and one can plan on it, let it fizzle out, or even use it to steer the situation in an orderly direction. 
In the field of football fans, however, the concept of provocation must be interpreted very broadly. This is because it is not important to have actually, deliberately provoked someone; what matters is that someone feels provoked. Provocation is therefore essentially in the eye of the beholder: the wrong kind of look or even looking away is already enough to be interpreted as provocation. In some situations, it seems like someone is seeking a reason for violence and then discovers - or, more precisely, constructs - a provocation in the body of the opponent they seek (cf. Keller et al., 2013).

In addition, actions may occur that all participants interpret as signs of increasing escalation. Representing a specific group, experienced virtuosos of insults or violence emerge from the group alone or in twos or threes to ritually insult the other group or throw objects, which leads to an intensification of the mutual insults and the consolidation of the other group: both the volume and type of insults, as well as their frequency, increase or become more intense. Crucial to the emerging dynamics of action in this phase is that not all participants in the gathering have the same attitude toward the use of violence-some actively seek it (and are prepared for it), others flirt with it, others fear it (Leistner, 2008, 2010; Stott \& Reicher, 1998a, b; Stott et al., 2001).

\section{Escalations}

However, it happens again and again that the situation suddenly changes, either through intentionally planned events or singular, situationally triggered events that did not originally carry the intention to commit an act of violence (Leistner, 2008). Individuals from the gathering (with instructions or without) punch each other for a certain relatively short amount of time (a few seconds), beat each other up, kick each other, spit or throw objects at each other, or hit each other with objects. This usually involves a mass of people trying to assert themselves individually or individual actions in very small groups, where several actors hit one victim on the ground or on the run (emotional dominance-see Collins, 2011, p. 112; also Nassauer, 2016, p. 508). Everyone acts in a frame in such a situation, but without a concrete script.

The dynamics set in motion in the groups involved ensure that action in the group is not uniform or synchronized; uniformity breaks down, and the behavior of individuals is no longer predictable and calculable (Stott \& Reicher, 1998a, b; Stott et al., 2001). Life-threatening weapons are generally not used. Experienced, violence-seeking actors then seek out "easy" opponents in pairs or threes (people lying on the ground, people who appear weak, individuals - see Collins, 2011, 2016). The rule here (depending on group affiliation) is that violence may legitimately be directed only at opposing ultras/active fans or at the police and law enforcement (also Leistner, 2010, p. 258). Attacking bystanders or "women and children" is considered a no-go. Agreement on this is unquestionable and frequently invoked.

This generally short phase of hitting, resisting, attacking, and fleeing is usually characterized by enormous stress and enormous uncertainty in action (even for those who are trained for such situations, like the police officers): Nobody knows whether the others will hit, kick, or throw, how hard and for how long they will do so, how long one has to do something, or what can even be done. Once violence is underway, for a short time everything becomes imponderable for everyone. The outcome is uncertain, and as for who will be harmed and how severe the harm will be, all of this is open, only becoming clear in the course of events. The social space that opens up for the participants when the situation shifts is therefore unmapped terrain for most: they can no longer coordinate their actions 
with one another unless they are trained for such situations and have a leadership structure that is also effective here.

Very quickly, however, the fights (attack, defend, retreat, win) disperse, and the fighters soon leave the scene individually or in small groups. Depending on which majority retreats or triumphs, all involved consider that they have defended and represented themselves fully, one group has won, or both have fought sufficiently well. Everyone leaves the field-beaten or victorious, but in any case with head held high (according to the subsequent narrative). No longer synchronized in its actions, the previously unified group disperses, breaking up into small groups that turn to each other and speak to each other, verbally reassuring themselves of their bravery and producing wordy narratives about the confrontation. The focus on a point of reference ends for now, as does the synchronization (parallelization) of behavior, even as co-orientation continues and the emotional arousal level drops (cooling down). At this point, the escalation process - fueled by new events - can start again.

This is one way to describe the process of the escalation of violence. All of this clearly indicates that the escalation process is not disorderly or even chaotic, but that this process has a pattern, an order, which can also be found in similar form in other escalation processes.

In escalations at and around German Bundesliga football matches, several groups (and subgroups) are directly and indirectly involved as actors. Escalations are never the result of the actions of a single group, instead resulting from the interaction (collusion) of several groups, which is why the question of responsibility (guilt) is not easy to answer. The following actors or groups are jointly responsible for the escalation process, which in its ideal, typical manifestation ultimately results in an outbreak of violence at or around a football match: various fan groups, private and state security forces, spectators, clubs, regional and national media (Reichertz, 2017), paramedics and fire fighters, fan supporters and the plethora of official and unofficial vendors, and, of course, the Internet with its possibilities of communicating in real time.

All of the actors mentioned here "play" together in the production of the event of going to the football stadium, albeit not all in the same place: Some have different "tasks" and responsibilities when there are clashes on match days, or when there are not. All of them are part of a big city performance that is publicly and collectively performed again and again on match days.

Violence in and around football stadiums does not erupt; it is brought about communicatively by the participants in a joint process. Because this is the case, social science analyses must examine the processes of communication and interaction that occur before violent acts occur, in detail and at all levels of action coordination.

\section{De-banalization of Everyday Life: Edgework or Collective Rite?}

For some observers, escalation processes result in the temporary collapse of the prevailing order. At a certain point, chaos seems to break out. However, if one adopts the considerations of Durkheim (1984) and Turner (1995), then it is precisely not a breakdown of order that occurs in such processes; instead, these ritually fenced-in processes lead to a new form of social order that is of central importance for participants, developing, transforming, securing, and also endowing both community and individual identity (see also Olaveson, 2001). 
For Durkheim, groups have a common collective reality and, correspondingly, collective representations. These collective realities, which individuals are not necessarily aware of, are expressed in common ritual acts that can only arise within groups. Newly performed again and again, such collective rites serve to express, maintain, or reestablish certain conceptions of reality and evaluations of the respective group (according to Durkheim, 1984).

Durkheim explains the meaning of these rituals based on the example of the way of life of Australian tribes: On the one hand, there is the everyday life of scattered communal living, and on the other hand, again and again, a short peak time of compression and fusion with others. This fusion with others, that is, the achievement of close, immediate connection with all others, is experienced by participants as remarkably gratifying and personality expanding. As a result of this extremely positive experience alone, those who have experienced such fusion once want to maintain the corresponding behavior and reach this state repeatedly. With a certain persistence and often with great effort, they strive to experience this state again - on the one hand, the state of community with others and, on the other hand, the accompanying gratifying experience of the de-banalization of everyday life (Wacquant, 2010, p. 20).

It is also possible to have this experience of the gratifying de-banalization of everyday life on other occasions, such as at concerts, festivals, demonstrations, and, of course, football matches. Society, as a rule, provides institutional offers (formats, dispositifs, etc.) that enable and contain the (almost) danger-free living-out of the de-banalization of everyday life. These offers nevertheless entail a moderate risk and thus they can often be experienced as (contained) adventures, or pleasurably occupied borderline experiences. However, these adventures are always episodic: They only last for a short time (a weekend, a vacation, etc.). After this emotionally intense time-out, for most people there is usually a return to safe normality, to banal everyday life.

In our youth culture, these excursions into adventure also include ritual confrontation with the authorities (for example, the police)—usually in extraordinary clothing and disguise - which is why Wickert speaks of a "carnival of crime" (Wickert, 2011). Stephen Lyng (following up on Goffman, 1967, 1971) created the term edgework for these excursions into adventure or return-ticket adventures, laying the foundation for a sociology of adventure in modern societies (Lyng, 1990, 2005). Accordingly, in largely regulated modern societies, voluntary, limited risk-taking of all kinds (bouldering, car racing, speculation on financial markets, shoplifting, regulated fighting among hooligans in rural fields etc.) is experienced not only as a seductive thrill but also as a partial reclamation of individual freedom and self-determination (Katz, 1988; Smith, 2005). In selfselected danger, one proves oneself, increases one's own competence, and demonstrates to everyone else that one is willing and able to act against the rules of the majority and thus set oneself apart from it. In addition, it triggers an intense emotion that is experienced as positive.

Edgework can thus be understood (within Foucault's theoretical horizon) as "techniques which permit individuals to effect, by their own means, a certain number of operations on their own bodies, their own souls, their own thoughts, their own conduct, and this in a manner so as to transform themselves, modify themselves, and to attain a certain state of perfection, happiness, purity, supernatural power" (Foucault, 1981). Edgework opens up the possibility for actors to experience and form themselves as sovereign, self-regulating subjects who seek out and face their own challenges (however small). 


\section{A Escape from the Pressure to Singularize?}

At the same time, there are good reasons to doubt whether the serial and passionate commitment to a football club, as currently practiced by active fans/ultras, actually constitutes edgework. Typical of edgework is the individual challenge and the individual proving of the self: edgework is above all about the self-determination of the individual and about singularization (Reckwitz, 2017). "Singularities are entities that are perceived and evaluated, fabricated and treated as particular within social practices. Singularities are the result of social-cultural processes of singularization. (...) If the general-particular denotes variation of the same, and idiosyncrasy denotes pre-social idiosyncrasy, then singularity is socioculturally fabricated uniqueness ${ }^{6}$ " (Reckwitz, 2017, p. 50-51).

Going to the football stadium, however, is always a group activity. The clothes, scarves, and stickers that fans wear on their bodies to dress up and make themselves highly visible and recognizable all refer to "their" club, symbolizing and invoking the club. The association is what connects the individuals and communitizes them without words. For symbols, as Soeffner puts it following Ludwig Klages, create "community without communication" (Soeffner, 2018, p. 107). Those connected with and through symbols are an immediate community. Without a doubt, in the communities that have come about in this way, there is also communication - often a great deal of very loud communication. But this noise is not a matter of whether and why the community exists (that goes without saying), but what the community does together and who the opponents are.

This is why going to the football stadium is specifically not about singularization. Indeed, the group is twice as important as the individual: First, the club is the supreme totem for which everyone must do everything; and second, supporting the club is always a collective task in which everyone must do their part. Individual particularity must always justify itself and must expect sanctions. Fans are only really themselves when they are together, similarly dressed, and doing similar things. The goal is not individualization, but inclusion.

When it comes to passionate football fans and their actions, it is neither a matter of individual self-improvement or self-enhancement, nor asceticism, control, rationality, or economic gain. Instead, for passionate fans, it is about the group, about friendship and enmity, about honor and respect, about flags and territory; they sing "battle chants" when they come together against the others. Passionate fans/ultras are all about the power of symbols and rites, about challenging and proving themselves, about winning or losing, about glory and recognition for the group and the club (and not about individual glory). The fans' narrative is tribalistic: It involves collective rituals and myths and the absorption of the individual into the group, not with the individual and the process of his or her self-emergence or even singularization.

Reckwitz's thesis that singularization is the new lifestyle of the new academically educated middle class (Reckwitz, 2017) meets its limit among passionate football fans, among whom there are also many academically educated young people. ${ }^{7}$ Alternately, one could

\footnotetext{
${ }^{6}$ Unless otherwise noted, citations from German texts were translated by Marius Glassner.

7 See also the critique by Jürgen Habermas: "Andreas Reckwitz has established a new view of society with constructive talent. If you will, he is the sociologist of the 'Generation Golf' (Illies). He has the vivid descriptive power of a David Riesman, but he re-purposes the latter's 'internally directed' character from a late-romantic colored libertarian view to what he believes is the authoritative 'externally directed' character in late modernity. The richness of the phenomena he opens up with this social character, eager to recognize its uniqueness, may impress. But it is precisely the relative decoupling of a socio-psychologically puffed-up
} 
assume that these young people take a short escape from the pressure to singularize on football weekends. Thus, if one wanted to uphold Reckwitz's thesis, one could say that for some, temporary ritual absorption in the group is a (necessary) compensation for the pressure to singularize during the week.

However, it would be very interesting and fruitful to investigate the question of whether a profound cultural struggle is currently taking place in football stadiums, namely, a struggle between the culture of communitization in the normal stands and the culture of singularization in the "padded business seats," that is, the leather VIP chairs. If singularization can be found anywhere, it is in these very expensive seats with free choice of food and drink (wine, champagne) along with "attentive hostess service." Yet one would need to empirically test and explain what the boundary work looks like at the boundaries of the VIP seats: Do VIPs allow themselves to be infected by the communal feeling of others, or is it the other way around - can the normal spectators and fans/ultras be won over to a culture of isolated enjoyment? Or is the VIP's visit to the stadium also a dearly paid attempt to experience emotionally intense, ritualistic absorption into the group for a limited time as a (necessary) compensation for the pressure to singularize during the week? Since nothing substantial is known so far about the use of football games by VIP guests, this remains speculation for the time being, and the clarification of these questions calls for further studies in the stadium.

\section{Second Theorization: Going to the Football Stadium as a Ritual Walk up to the Boundaries of the Social}

From the perspective developed here, violence does not-ever-occur by chance in football stadiums, nor does something unpredictable escalate: escalations are socially preformed because they are ritualized. Ultimately, they do not serve to eliminate the opponent, instead essentially serving to communitize, to form one's own group and one's own identity. They have the effect of building stable mutual expectations of behavior among all the groups involved. Violence does not aim at the destruction of the other, but at one's own formation, which sometimes also involves accepting the injury of the other or at least reckoning with this possibility.

Collective attendance of German Bundesliga football matches and the collective surge of emotion that gradually emerges in the process are part of a now institutionalized and highly ritualized habit of behavior; this behavior, which first had to emerge historically, involves specific socialization processes for its actors. Thus, various rituals have emerged as a kind of score for action. There are ritual masters who indicate which score is to be played when, making sure that as many people as possible seriously participate in this ritual. Among the ritual masters there is also a high nobility and a low nobility, that is, those who have a lot to say and those who have little to say. There are those who are experienced, those who have just been initiated or those who are applying for initiation, and of course there are a multitude of spectators who not only observe the rite, but also witness it through

Footnote 7 (continued)

culture from those socio-structural dislocations that are ultimately triggered by functional imperatives of a globally deregulated world market that does not convince me. One turns causalities upside down, after all, if neoliberal deregulated competition is supposed to reflect only the inherent cultural logic of 'recognition markets", (Habermas, 2020: 7). 
their presence and make it possible in the first place. The ritual, interrelated acts of cheering, taunting and mocking, communitizing, provoking and hitting each other that unfold at such large-scale events are embedded in a (sub)culture that has evolved locally and historically, thereby developing forms of socialization and sanctions for the actors.

This football culture looks back on a long tradition that transcends the individual in every way, thus placing the individual in a historical, supra-temporal community that is directed toward a specific goal. Exaggerating the positions of Durkheim (1984) and Goffman (1967), one could say that the regular outbreak of violence around football matches in urban spaces can also be understood as a specific interaction ritual: the regular, highly ritualized, shared seeking and treading of the boundaries of what is socially endorsed. Going to football stadiums, so my thesis, can be understood as testing the boundaries of the socially acceptable. It is not only the active and rival fans/ultras who are involved in this ritual, but without a doubt also the police officers. This ritualized treading of the boundaries of what is socially approved also serves the revitalization and sometimes the renewal of the social aspect of the (sub)culture of football in (post)modern times.

Funding Open Access funding enabled and organized by Projekt DEAL.

Open Access This article is licensed under a Creative Commons Attribution 4.0 International License, which permits use, sharing, adaptation, distribution and reproduction in any medium or format, as long as you give appropriate credit to the original author(s) and the source, provide a link to the Creative Commons licence, and indicate if changes were made. The images or other third party material in this article are included in the article's Creative Commons licence, unless indicated otherwise in a credit line to the material. If material is not included in the article's Creative Commons licence and your intended use is not permitted by statutory regulation or exceeds the permitted use, you will need to obtain permission directly from the copyright holder. To view a copy of this licence, visit http://creativecommons.org/licenses/by/4.0/.

\section{References}

Bauer, S. (Ed.). (2006). Helden - Heilige - Himmelsstürmer: Fußball und Religion. Legat-Verlag.

Beck, U. (2015). Risikogesellschaft. Auf dem Wege in eine andere Moderne. Suhrkamp.

Beck, U., \& Beck-Gernsheim, E. (Eds.). (1994). Riskante Freiheiten. Individualisierung in modernen Zeiten. Suhrkamp.

Claus, R. (2017). Hooligans. Eine Welt zwischen Fußball, Gewalt und Politik. Dortmund: Werkstatt.

Collins, R. (2011). Dynamik der Gewalt. Eine mikrosoziologische Theorie. Hamburger Edition.

Collins, R. (2016). Einfahrten und Ausfahrten des Tunnels der Gewalt. In C. Equity, A. Groenemeyer \& H. Schmidt (Eds.) Situationen der Gewalt (pp. 14-39.). Weinheim: Juventa.

Couldry, N., \& Hepp, A. (2016). The Mediated Construction of Reality. Polity Press.

Degen, J., Bal, P.M. \& Kleeberg-Niepage, A. (2020). Lost in Context: Call for Human Arena Special Section. MS.

Degen, J. \& Kleeberg-Niepage, A. (2021). Profiling the Self in Mobile Online Dating Apps: A Serial Picture Analysis. Human Arena.

Durkheim, E. (1984). Die elementaren Formen des religiösen Lebens. Suhrkamp.

Feltes, T. (Ed.). (2013). Polizei und Fußball. Polizeiwissenschaft.

Fromm, B. \& Reichertz, J. (2002). "Zeig mir Dein Gesicht, zeig mir, wer Du wirklich bist." Masken des Authentischen oder The Comeback of Public Man. In M. Schweer, C. Schicha \& J. Nieland (Eds.). Das Private in der öffentlichen Kommunikation, pp. 77-104. Cologne: Herbert von Harlem Verlag.

Foucault, M. (1981): Sexuality and Solitude. London Books of Review, 3, 9. https://www.lrb.co.uk/thepaper/v03/n09/michel-foucault/sexuality-and-solitude.

Genov, N. (2018). Challenges of Individualization. Palgrave Macmillan.

Giddens, A. (1997). Konsequenzen der Moderne. Suhrkamp.

Giddens, A. (2001). Die entfesselte Welt. Suhrkamp. 
Giddens, A. (2013). The Constitution of Society. University of California Press.

Goffmann, E. (1963). Behavior in Public Places. Notes on the Social Organization of Gatherings. The Free Press.

Goffman, E. (1967). Interaction Ritual. Transaction Publisher.

Goffman, E. (1971). Relations in Public. Transaction Publisher.

Gross, P. (1994). Die Multioptionsgesellschaft. Suhrkamp.

Habermas, J. (2020). Moralischer Universalismus in Zeiten politischer Regression. Jürgen Habermas im Gespräch über die Gegenwart und sein Lebenswerk. Leviathan, 48, 1, 7-28. https://docplayer.org/ 202347470-Moralischer-universalismus-in-zeiten-politischer-regression.html. Accesed 05.06.2021

Hepp, A. (2019). Deep Mediatization. Routlegde.

Katz, J. (1988). Seductions of Crime. Basic Books.

Keller, R., Knoblauch, H., \& Reichertz, J. (Eds.). (2013). Kommunikativer Konstruktivismus. Springer.

Keysers, V. (2018). Die Genealogie des Duckface. Zur kommunikativen Konstruktion mediatisierten Wirklichkeit. In J. Reichertz \& R. Bettmann (Eds.) Kommunikation - Medien - Konstruktion, pp. 141-170. Wiesbaden: Springer VS.

Knoblauch, H. (1991). Die Verflüchtigung der Religion ins Religiöse. In T. Luckmann. Die unsichtbare Religion, pp. 7-44. Frankfurt am Main.

Leistner, A. (2008). Zwischen Entgrenzung und Inszenierung: Eine Fallstudie zu Formen fußballbezogener Zuschauergewalt. Sport Und Gesellschaft, 5(2), 111-133.

Leistner, A. (2010). Fans und Gewalt. In J. Roose, M.S. Schäfer \& T. Schmidt-Lux (Eds.): Fans. Soziologische Perspektiven, pp. 249-279. Wiesbaden: Springer.

Luckmann, T. (2010). Die unsichtbare Religion. Suhrkamp.

Lyng, S. (1990). Edgework: A Social Psychological Analysis of Voluntary Risk Taking. American Journal of Sociology, 95(4), 851-886.

Lyng, S. (Ed.). (2005). Edgework: The Sociology of Risk Taking. Routledge.

Nassauer, A. (2016). Theoretische Überlegungen zur Entstehung von Gewalt in Protesten: Eine situative mechanismische Erklärung. Berliner Journal Für Soziologie, 25, 491-518.

Olaveson, T. (2001). Collective Effervescence and Communitas: Processual Models of Ritual and Society in Emile Durkheim and Victor Turner. Dialectical Anthropology, 26, 89-124.

Paris, R. (2015): Der Wille des Einen ist das Tun des Anderen. Weilerswist: Velbrück.

Pfadenhauer, M. \& Hitzler, R. (2020). Individualisierungsfolgen. Einige wissenssoziologische Anmerkungen zur Theorie reflexiver Modernisierung. In A. Poferl \& Sznaider, N. (Eds.): Ulrich Becks kosmopolitisches Projekt: auf dem Weg in eine andere Soziologie, pp. 123-136. Baden-Baden: Nomos Verlag.

Poferl, A. (1999). Gesellschaft im Selbstversuch. Soziale Welt, 50(4), 29-38.

Poferl, A. (2019). Die Verortung des Subjekts. Herausforderungen der Globalisierungsforschung und Überlegungen zu einer nachgesellschaftlichen Gesellschaftstheorie. SFB 1265 Working Paper, 3.

Poferl, A., \& Sznaider, N. (Eds.). (2020). Ulrich Becks kosmopolitisches Projekt: Auf dem Weg in eine andere Soziologie (pp. 123-136). Nomos Verlag.

Reckwitz, A. (2017). Die Gesellschaft der Singularitäten. Suhrkamp.

Reckwitz, A. (2019). The Society of Singularities. Polity Press.

Reichertz, J. (2000). Die Frohe Botschaft des Fernsehens. Konstanz.

Reichertz, J. (2009). Kommunikationsmacht. Was ist Kommunikation und was vermag sie? Und weshalb vermag sie das? Wiesbaden: VS Verlag.

Reichertz, J. (2010). Das sinnhaft handelnde Subjekt. In B. Griese (Ed.), Subjekt - Identität - Person (pp. 21-48). Wiesbaden. VS Verlag.

Reichertz, J. (2015). Communication, Identity, and Power. In P. Meusberger, D. Gregory \& Laura Suarsana (Eds.). Geographies of Knowledge and Power, pp. 315-333. Dordecht: Springer Netherlands.

Reichertz, J. (2017). Die Bedeutung des kommunikativen Handelns und der Medien im Kommunikativen Konstruktivismus. Themenheft der Zeitschrift Medien \& Kommunikationswissenschaft, 252-274.

Reichertz, J. (2019). Automating Security in and Around Football Stadiums Through Camera Systems? Report on a Research Project. European Journal for Security Research, 5, 1-23. Accessed at, DOI https://doi.org/10.1007/s41125-019-00056-7, Accessed 02.06. 2021

Reichertz, J. (Eds.). (2020). Grenzen der Kommunikation - Kommunikation an den Grenzen. Weilerswist: Velbrück.

Reichertz, J. (2021). Limits of interpretation or interpretation at the limits: Perspectives from hermeneutics on the re-figuration of space and cross-cultural comparison [69 paragraphs]. Forum Qualitative Sozialforschung/Forum: Qualitative Social Research, 22(2), Art. 18. http://dx.doi.org/10.17169/fqs-22.2. 3737. FQS http://www.qualitative-research.net/. Accessed 12 February 2021.

Reichertz, J., \& Keysers, V. (Eds.). (2018). Emotion. Eskalation. Gewalt. Springer. 
Roose, J., Schäfer, M., \& Schmidt-Lux, T. (Eds.). (2017). Fans. Soziologische Perspektiven. Springer.

Smith, C. (2005). Financial Edgework: Trading in Market Currents. In S. Lyng (Ed.), Edgework: The Sociology of Risk-Taking (pp. 187-200). Routledge.

Soeffner, H. G. (1994). Das 'Ebenbild' in der Bilderwelt - Religiosität und die Religionen. In W. M. Sprondel (Ed.), Die Objektivität der Ordnungen und ihre kommunikative Konstruktion (pp. 291-317). Suhrkamp.

Soeffner, H.G. (2007). Methodologischer Kosmopolitismus. In J. Dreher \& P. Stegmeier (Eds.). Zur Unüberwindbarkeit kultureller Differenz, pp. 97-112. Bielefeld: transcript.

Soeffner, H. G. (2018). Mythenpolitik - High Noon in der politischen Auseinandersetzung. In: P. Stoelger \& Kumlehn, M. (Eds.) Bildmacht, pp. 95-108. Würzburg: Königshausen \& Neumann.

Spiekermann, N. (2018). Heey, was soll das? Solidarisierung unter Fussballfans als Reaktion auf polizeiliche Maßnahmen. In J. Reichertz, \& Keysers, V. (Eds). Emotion. Eskalation. Gewalt, pp. 91-114. Weinheim: Juventa.

Stott, C., \& Reicher, S. (1998a). How Conflict Escalates: The Inter-group Dynamics of Collective Football Crowd Violence. Sociology, 32, 353-377.

Stott, C., \& Reicher, S. (1998b). Crowd Action as Intergroup Process: Introducing the Police Perspective. European Journal of Social Psychology, 28, 509-529.

Stott, C., Hutchison, P., \& Drury, J. (2001). "Hooligans" Abroad? Inter-group Dynamics, Social Identity and Participation in Collective "Disorder" at the 1998 World Cup Finals. British Journal of Social Psychology, 40, 359-384.

Strohschneider, P. (2020). Zumutungen. Wissenschaft in Zeiten von Populismus, Pluralisierung und Scientokratie. Hamburg: Kursbuch Kulturstiftung.

Turner, V. (1995). Vom Ritual zum Theater. Fischer Verlag.

Wacquant, L. (2010). Leben für den Ring. Konstanz: UVK.

Wanke, J. (2001). Das Evangelium auf den Leuchter stellen. In M. Entrich \& J. Wanke (Eds.), In einer fremden Welt (pp. 13-30). Stuttgart.

Wickert, C. (2011): Krawall und Kommerz. www.criminologia.de/2011/05/krawall-und-kommerzwattebauschchenschmeisen-am-1-mai/ (Abfrage: 20.08. 2020).

Publisher's Note Springer Nature remains neutral with regard to jurisdictional claims in published maps and institutional affiliations. 